La unidad didáctica de Educación Física y Deporte en Educación a Distancia: Análisis de contenido de videos en Youtube.

\title{
Physical Education and Sports Lesson in Distance Education: Content Analysis of Videos on Youtube.
}

\author{
Mehmet Akif Yücekaya. \\ Ministry of Education, Turkey. \\ yucekayaakif@gmail.com \\ Ahmet Enes Sağin. \\ Ministry of Education, Turkey. \\ a.enesagin@outlook.com \\ Sinan Uğraş. \\ Çanakkale Onsekiz Mart University, Turkey. \\ sinanugras@gmail.com
}

\section{RESUMEN}

En este estudio, se tuvo como objetivo examinar cómo los profesores de educación física y deportes impartían lecciones en el proceso de educación a distancia y qué actividades incluyeron en el contenido del curso durante el proceso pandémico de Covid 19. Se analizaron los videos publicados bajo el título de educación a distancia, educación física y lecciones deportivas escritas en turco en YouTube. Los videos se analizaron mediante la técnica de análisis de contenido. Se obtuvieron tres temas como resultado del análisis de contenido. Estos son los temas de "juegos educativos", "práctica" y "expresión teórica". Como resultado del estudio, se concluyó que se intentó atender a las necesidades de movimiento de los estudiantes a través de vídeos subidos a YouTube bajo el título de educación a distancia, educación física y lecciones deportivas y lo que los estudiantes deben hacer para proteger su salud. El trabajo se sustenta en información en el marco de "salud - deportes" y se intentó hacer divertido el proceso a través de juegos educativos durante el período de permanencia en casa. Se recomienda proporcionar un curso de capacitación para maestros sobre cómo manejar las lecciones de educación física y deportes a través de la educación a distancia, especialmente en el proceso de la pandemia Covid 19.

\section{PALABRAS CLAVE.}

Educación a distancia, Youtube, educación física y deporte.

\section{ABSTRACT.}

In this study, it was aimed to examine how physical education and sports teachers taught lessons in the distance education process and which activities they included in the course content during the Covid 19 pandemic process. The videos published under the title of distance education physical education and sports lessons written in Turkish on YouTube were analyzed. The videos were analyzed using content analysis technique. Three themes were obtained as a result of the content analysis. These are the themes of "educational games", 
"practice" and "theoretical expression". As a result of the study, it was concluded that it was tried to meet the movement needs of students through videos uploaded to YouTube under the title of distance education physical education and sports lessons, what students should do to protect their health is supported by information within the framework of "health - sports" and it was tried to make the process fun through educational games during the period of staying at home. It is recommended to provide an in-service training course for teachers on how to handle physical education and sports lessons through distance education, especially in the Covid 19 pandemic process.

Keywords: Distance education, Youtube, physical education and sports.

\section{Introduction.}

Some unusual events that change the order of daily life in the world cause some changes in many areas. It can be stated that wars, natural disasters and epidemics are the leading ones. The coronavirus (Covid-19) epidemic, which has surrounded the whole world since the end of 2019, has started to show its effects all over the world in a short time, there have been approximately 34 million patients and over 1 million deaths (Who, 2020). After the Spanish flu that occurred in the 1st World War, there was no other epidemic event that affected people's social, economic and life styles to this extent (Woods et al, 2020). Many sectors have been negatively affected by the epidemic. Along with the field of health, one of the areas most negatively affected in this process was education. It has been stated that approximately 770 million people worldwide have disruptions in their education due to the epidemic (Zhong et al., 2020). Schools were closed in Turkey based on the isolation theory that reduces the transmission rate of the disease (Jackson, Vynnycky \& Mangtani, 2016). In a study that supports this theory, it was reported that the epidemic decreased by the rate of $29.7 \%$ by closing schools (Nafisah, Alamery, Al Nafesa, Aleid \& Brazanji, 2018). The results of this kind of research led the authorities to decide to switch to distance education during the coronavirus epidemic. As in many parts of the world, the Ministry of National Education in Turkey decided yo switch distance education and the education was carried out on TRT (The Turkish Radio and Television Corporation) EBA TV and the online platform EBA. EBA, which stands for "Eğitim Bilişim Ağı (Educational Informatics Network)", is a structure that includes many materials such as video, document, e-book and tests for students from pre-school to high school since the 2011-2012 academic year (Özer, 2020). During the epidemic period, EBA has been the main system for reaching students with live lessons. In addition, teachers used utilities such as zoom, Microsoft teams, YouTube, as well as the EBA platform to reach their students. Physical education and sports lessons have been included in distance education as other lessons.

The concept of distance education can be defined as the individuals who have problems or do not prefer face-to-face education, performing planned and scheduled learning activities by using some utilities (Altıparmak, Kurt, \& Kapıdere, 2011). Although distance education emerges out of necessity over time, it has become an important option later on. Distance education is not a concept that emerged during the epidemic period we live in. There are sources stating that distance education started in the early 1700 s and it is mentioned in the 
sources that it started in 1840 in England (Kırık, 2014). Later, technological developments in the historical process caused the tools used in distance education to change. Distance education, which started with the letter, continued with many auxiliary devices such as radio, television, cable channels, computers, tablets and mobile phones. While distance education was first implemented in the USA at university level (Yalçınkaya, 2006), it was started to be carried out in Australia and Japan respectively in primary and secondary education (Kırık, 2014; Özbay, 2015). In Turkey, the first example of distance education was carried out in 1927 with a letter for the reasons arising from physical problems (Aral, 1999). However, it was not efficient until the "Letter Education Center" was established in 1960 (Kaçan and Incoming, 2020). Distance education at the university level started to be realized with the "Open Education Faculty" within Anadolu University in 1981 (Gelli, 2015), after the "Open Education High School" in 1992, the "Open Primary School" started to provide education in 1998 (Demiray and Adıyaman, 2002). Today, the rate of application of distance education programs at associate degree, undergraduate and graduate level has reached $80 \%$ (Özbay, 2015).

Distance education is carried out for various purposes today. In addition to secondary school, high school, associate degree, undergraduate diplomas, distance education is frequently used in some certificate programs. There are many reasons for this. Web-based distance education has become widespread in recent years. Web-based distance education is flexible and suitable for student needs (Allen \& Seaman, 2016). It has low cost (Odabaş, 2003; Xu \& Xu, 2019). It provides more effective use of time. It is effective in wider area (Lei \& Gupta, 2010). It offers synchronous and asynchronous access between students and teachers (Kırık, 2014). These can be counted as its advantages of web-based distance education.

With the start of the epidemic period, a compulsory home closure process occurred. Although restrictions reach a flexible structure in certain periods, people have had to move towards a more sedentary life with the fear of getting sick. This process negatively affected children and young people as well as adults. It has been stated that with the closure of schools, it can increase childhood obesity in the long term (Rundle et al., 2020; Workman, 2020). Von Hippel and Workman (2016) stated that obesity prevalence of children they followed for 3 years increased during summer vacation. This result shows that schools are associated with physical activity for children. With isolation, cardiovascular disease risk, unhealthy lifestyle and negative symptoms occur in anxiety levels may occur (Mattioli et al, 2020). In the study conducted by Pietrobelli et al. (2020), it was reported that the use of potato chips, red meat and sugar increased, sports activities decreased, time spent in front of the screen and sleep time increased. It has been stated that the isolation period can trigger not only physical effects but also depression and post-traumatic disorders in individuals (Brooks et al, 2020). Studies have shown that children who engage in high-intensity physical activity have a low fat ratio (Sardinha, Marques, Minderico \& Ekelund, 2017) and there is a close relationship between physical activity and obesity (Muntaner-Mas et al, 2017).

Students can perform physical activities through physical education and sports lessons or extracurricular sports activities. Physical activity has many psychological and sociological benefits (Valois, Zullig, Huebner \& Drane, 2004; Zullig \& White, 2011). However, the covid 19 outbreak has restricted physical activity in all people. In many countries, both indoor and outdoor sports areas were closed. Schoolwork and social communication started to be applied

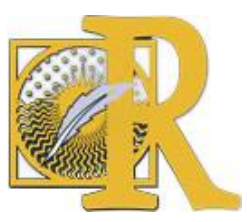

Fecha de recepción: 09-03-2021 Fecha de aceptación: 01-05-2021

Yücekaya, M., Sağin, A. \& Uğraş, S. La unidad didáctica de Educación Física y Deporte en Educación a Distancia: Análisis de contenido de videos en Youtube 
online (Shahidi, Stewart Williams \& Hassani, 2020). However, during the isolation period, the opportunities for children and young people to do physical education and sports lessons and sports activities effectively decreased. Although there are studies showing that physical education lessons can be taught through distance education (Silva, Silva \& Silva, 2019; Yaman, 2009), considering the natural difficulties in effectively teaching and evaluating physical activities online, physical education and sports lessons are quite likely to be difficult (Goad, 2019; Ivanov \& Tzankova 2020). One of the lessons affected by the Covid 19 pandemic is the implementation of physical education. Many students see physical exercise only in physical education classes in schools (Founaud \& González-Audicana, 2020). While other courses allow the curriculum to be made largely through distance education, it is likely that some difficulties may be experienced in the implementation of physical education and sports lessons. Based on the sources they examined, Cachón-Zagalaz et al. (2020) stated that the importance of physical education activities was emphasized in this process and the rates of sedentaryism increased in this process. Akalın and Gümüş (2020) stated in their study that students' participation in physical education and sports lessons in distance education is very low. It is thought that many reasons such as how physical education and sports teachers conduct their lessons in distance education, what activities they include, whether they do the lesson theoretically or practically, and students 'and parents' approaches to physical education and sports lessons in distance education can affect the participation in the lesson. The lack of any suggestions or programs of the Ministry of National Education on how physical education teachers should follow this process caused teachers to carry out this process with their own plans. In this study, it was aimed to examine how physical education and sports teachers teach lessons in the distance education process and which activities they include in the course content.

\section{Method.}

In this study, the videos posted on YouTube, one of the social media tools, under the title of distance education physical education and sports lesson, were analyzed. In the study, videos were analyzed using content analysis technique. In content analysis, which is among the most frequently used qualitative research methods (Elo \& Kyngäs, 2008); It is tried to reach conceptual conclusions by classifying and comparing the collected data within the framework of the problem or purpose (Mayring, 2014). Content analysis is used in newspaper, magazine, advertisement, narrative, film, TV and so on. It is used in a wide range of fields (Macnamara, 2005).

\subsection{Population and Sample.}

The videos uploaded specific to Turkey under the title of physical education and sports lesson in distance education on YouTube ( on October 27, 2020) constitute the population of the video. The criterion sampling method was preferred in selecting the sample group examined in the study. In this method, the person, event, object or situation that meets the predetermined criteria is included in the study (Patton, 2002). In this study, the criteria sought in videos are: 
- Uploading of videos to YouTube since March 2019: Videos uploaded since March 2019 were included in the study. A search was made on a YouTube using the expression physical education and sports class in distance education on 27 October 2020. A limitation has been attempted to be imposed on the numerous video content resulting from pre-search. For this reason, as a result of the increase in the importance and popularity of distance education with the closure of schools due to the Covid 19 epidemic all over the world in March 2019 (la Velle, Newman, Montgomery, \& Hyatt, 2020; Tzifopoulos, 2020), it has been observed that the number and visibility of content on YouTube, especially about physical education and sports, has increased. For this reason, the videos are filtered according to their upload date.

- The compatibility of the search title and the content: When the expression of " physical education and sports lesson in distance education " is entered on YouTube, 2720 videos have been encountered. 130 videos were included in the study. The reason for this number is that many videos encountered with search results do not overlap and many search engines, including YouTube, present the results with an artificial prediction (Cheng, Dale, \& Liu, 2008). Therefore, only some of these videos could be included in the study.

\subsection{Classification and Analysis of Video Content.}

The main purpose of the content analysis process is to explain the collected data through concepts and relationships (Yıldırım \& Şimşek, 2011). In this process, the coding analysis of $10 \%$ of the videos determined about physical education lessons in distance education were carried out independently by 3 researchers. A coding guide has been created according to the code compliance and definitions for the videos that the coders analyze the content. Later, the remaining videos were analyzed. Since there was hesitation in the code analysis of some analysis, in order to reach a consensus, the coders were gathered once more and the compatibility between the coders was achieved. After the analysis of all the videos was completed, the codes and themes created were realized by the researchers in a consensus. The analysis of the data was made in the qualitative data analysis program of Maxqda. It has been observed that some of the video contents contain different activities. For example, it has been determined that some videos contain several branch introductions or different activities. For this reason, a large number of codes can come out from a video. 


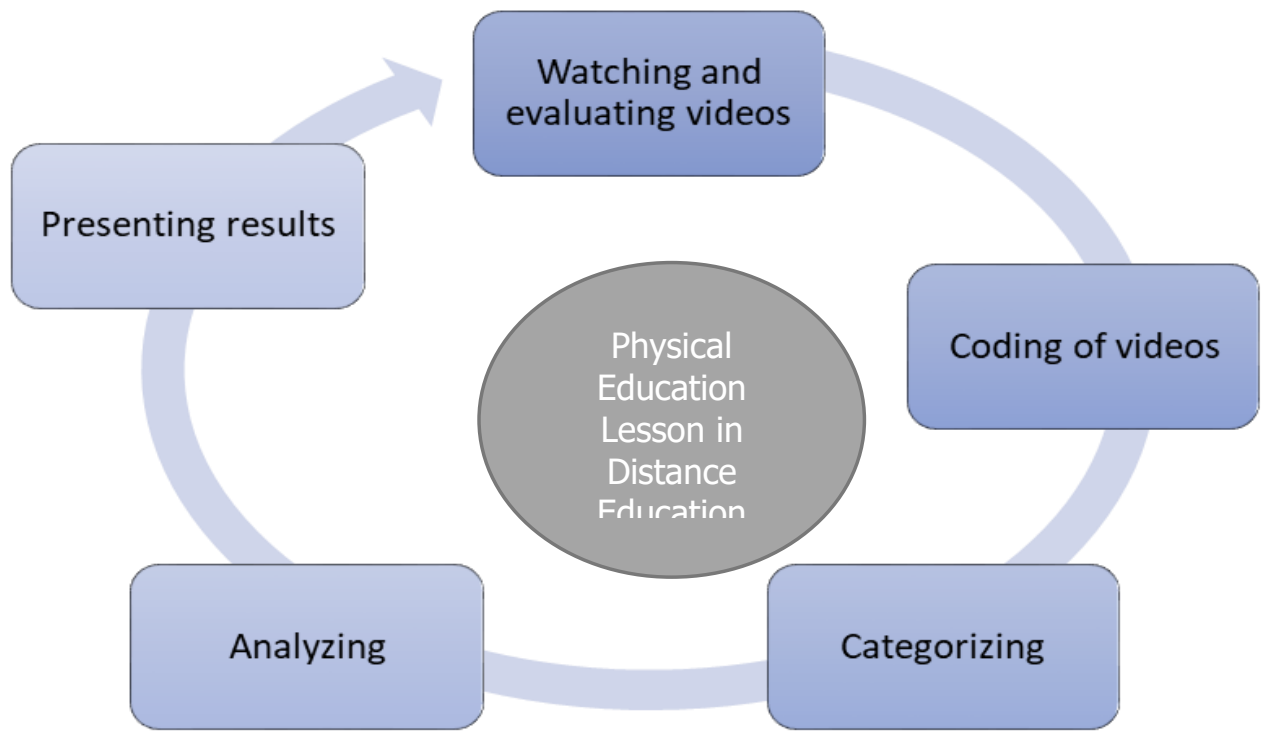

Figure 1. Cyclical process of the study

\section{Findings.}

In this section, the content analysis of the videos about physical education course in the distance education on YouTube was made. Then, categories were created based on the revealed codes and themes were reached from the categories. As a result of the content analysis, three themes emerged under the main theme of "distance physical education and sports lesson content". These are the subthemes of "educational games", "practice" and "theoretical expression". The features of the videos in the study are shown in table 1.

Table 1. Features of the videos examined in the study

\begin{tabular}{lccc}
\hline Video Type & Video number $(\mathrm{f})$ & Percentage $(\%)$ & Average Course Duration \\
\hline Animation & 25 & 19.5 & $16.33 \mathrm{~min}$ \\
Real Person & 103 & 80.5 & $14.21 \mathrm{~min}$ \\
Total & 128 & 100 & $15.27 \mathrm{~min}$ \\
\hline
\end{tabular}

The quantitative characteristics of the videos included in the study are shown in Table 1. The average video duration of the videos uploaded to YouTube, $19.5 \%$ of which is in the form of animation, is 16 minutes, while the average number of views is 14 thousand. On the other hand, 80.5 of the analyzed videos consist of activities performed by real people on the screen. While the average course time of these videos is 14 minutes, the average number of views is 4 thousand. The average duration of 128 videos in total is 15 minutes, and the average number of views is 9 thousand. 


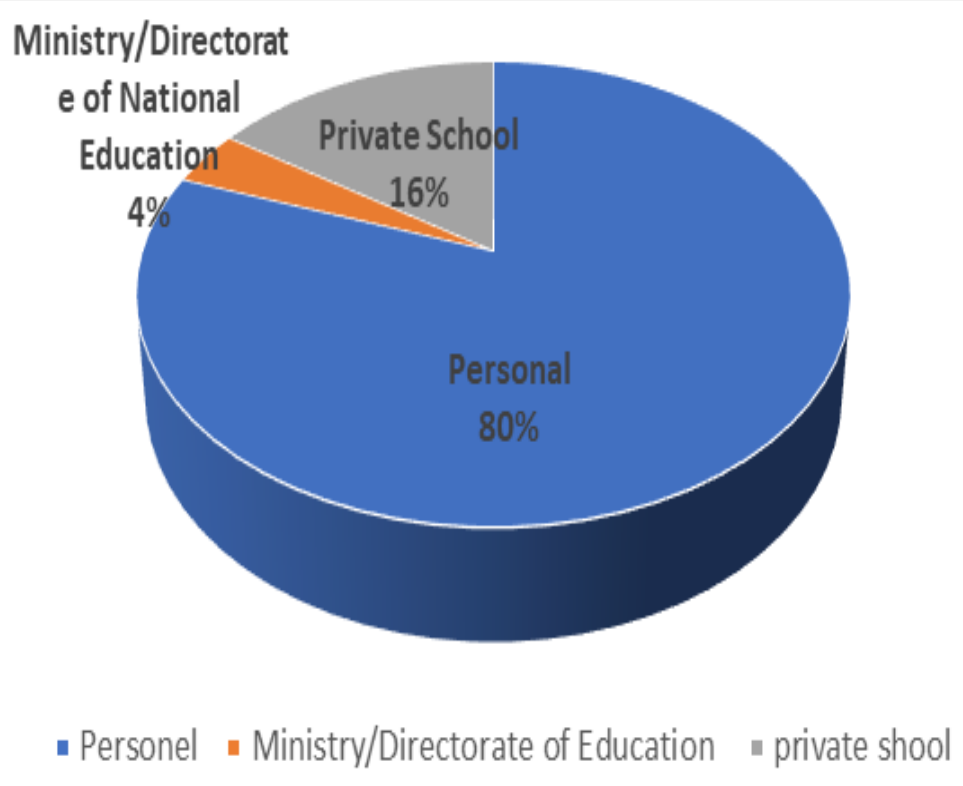

Graphic 1. Distribution of uploaded videos by channels

As shown in Graphic 1, 80\% of the content uploaded to YouTube was uploaded from personal accounts, $16 \%$ from private schools' accounts and $4 \%$ from the accounts of the Ministry/Directorate of National Education.

Within the scope of the study, videos analyzed in content were presented under the main theme of "distance physical education and sports lesson" as three themes. $56 \%$ (86) of the video contents were under the "practice" theme based on movement, $28 \%$ (44) under the "theoretical explanation" theme which was theoretically based, and $15 \%(23)$ were under the "educational games" theme in game format. It is presented below. The theme categories and codes presented under the main theme of "distance physical education and sports lesson" and their frequency values are shown in Figure 1. 


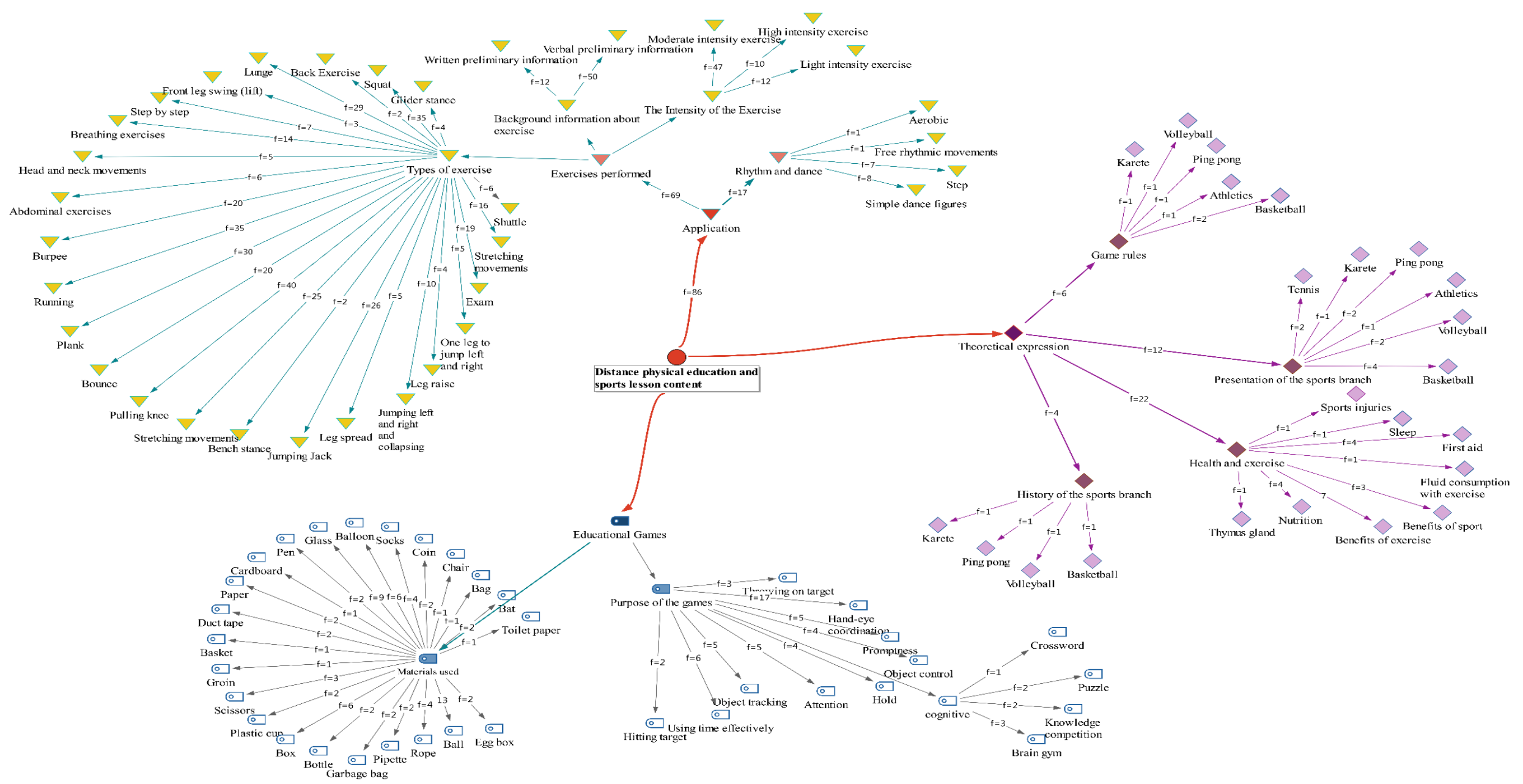

Figure 2. Main theme of distance physical education and sports lesson content. 


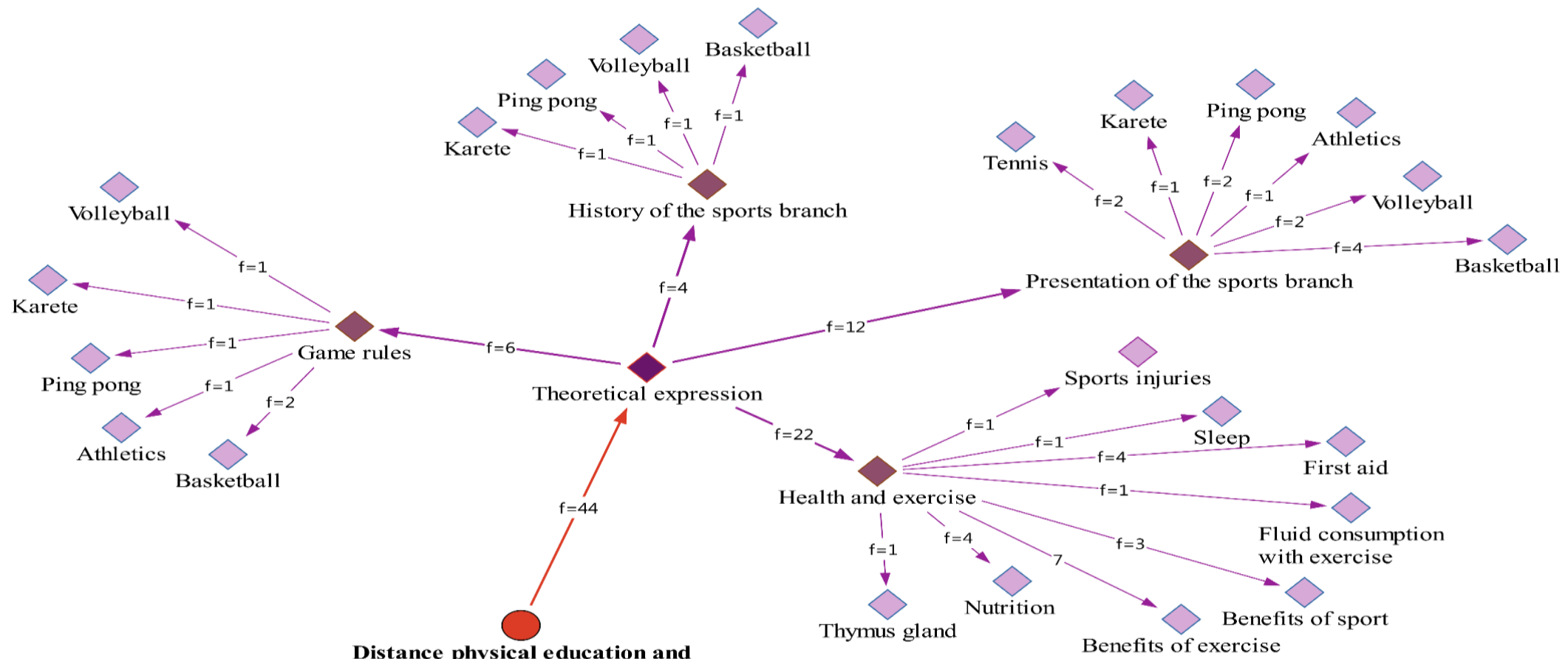

Distance physical educa
sports lesson content

Figure 3. Theoretical narrative theme.

In Figure 3, categories and codes belonging to the theme of theoretical expression and their frequency values can be seen. These; It consists of 4 categories: health and exercise $(f=22)$, history of sports branches $(f=12)$, history of sports branches $(f=4)$, and game rules $(6)$. While physical education and sports teachers create their course content, besides the sports branches such as basketball, volleyball, etc., which are widely played in schools, they also include sports branches such as karate and tennis, which are less popular, on the other hand it has been determined that there is no video content for nature sports, water sports, winter sports, developing sports, etc. It is observed that physical education and sports teachers generally prefer the sports branches that students have prior knowledge when preparing content. In another category, while the video content includes general titles such as First Aid, Benefits of Sport, Benefits of Exercise, specific subjects such as thymus gland and sleep are also mentioned. 


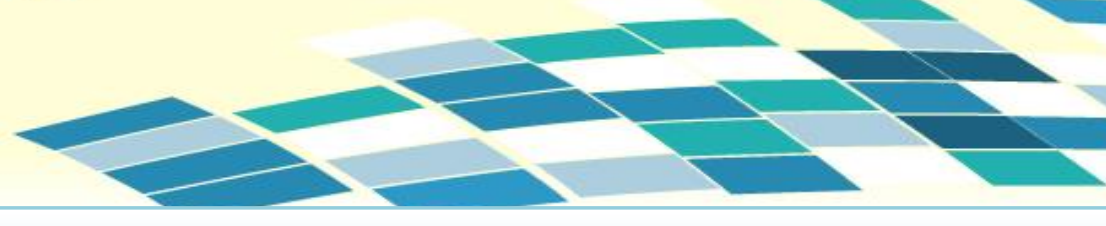

Mehmet Akif Yücekaya, Ahmet Enes Sağin \& Sinan Uğraş. La unidad didáctica de Educación Física y Deporte en Educación a Distancia: Análisis de contenido de videos en Youtube

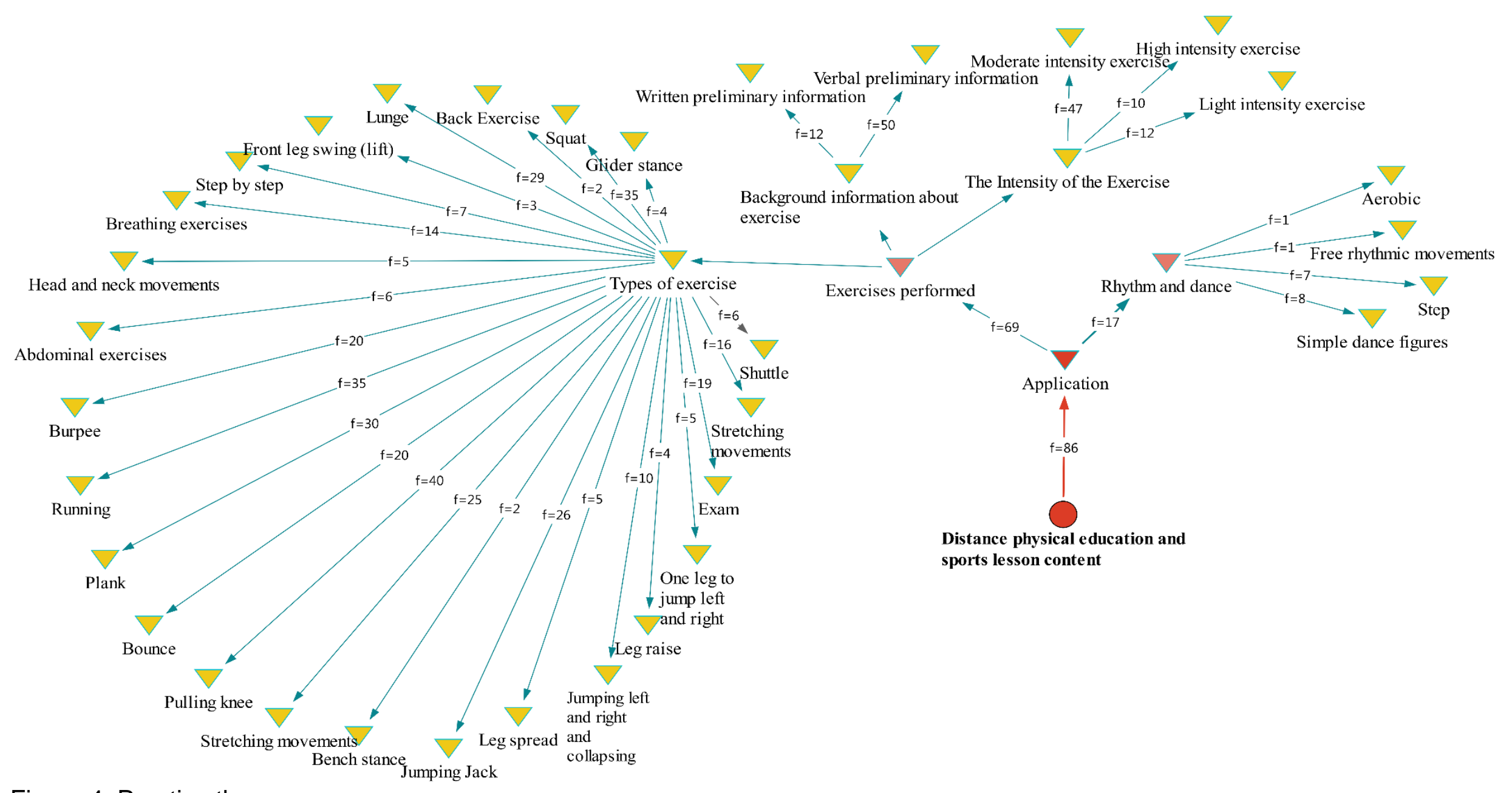

Figure 4. Practice theme. 
Looking at the practice theme in Figure 4, it is seen that the theme consists of the exercises performed $(f=69)$ and the category of rhythm and dance $(17)$. In this theme, which constitutes the majority of the videos on Youtube, a significant part of the content is for students to work different body parts. In the videos about exercise, physical education and sports teachers generally explain the exercise for students verbally or in writing, and it is striking that the majority of the movements they choose are moderate intensity exercises. On the other hand, it is seen that the teachers make students do simple dance moves, rhythmic movements, step and aerobics. In general, it was observed that the contents were created at a basic level and in a way that all students can be included in a home environment.

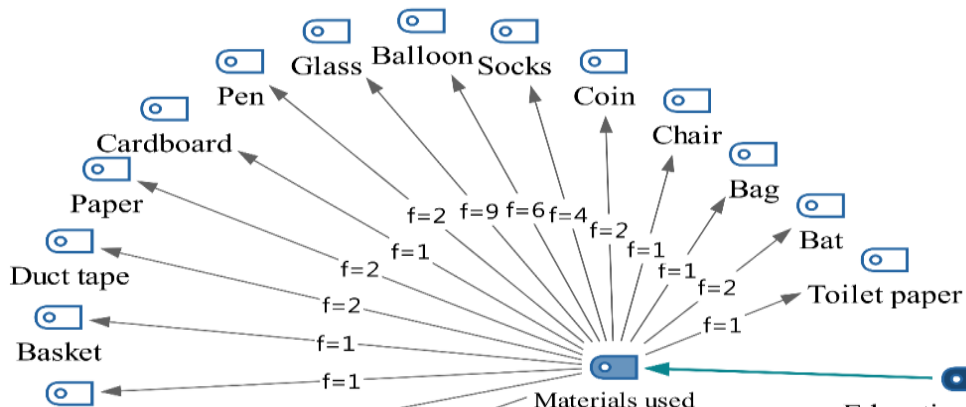

○

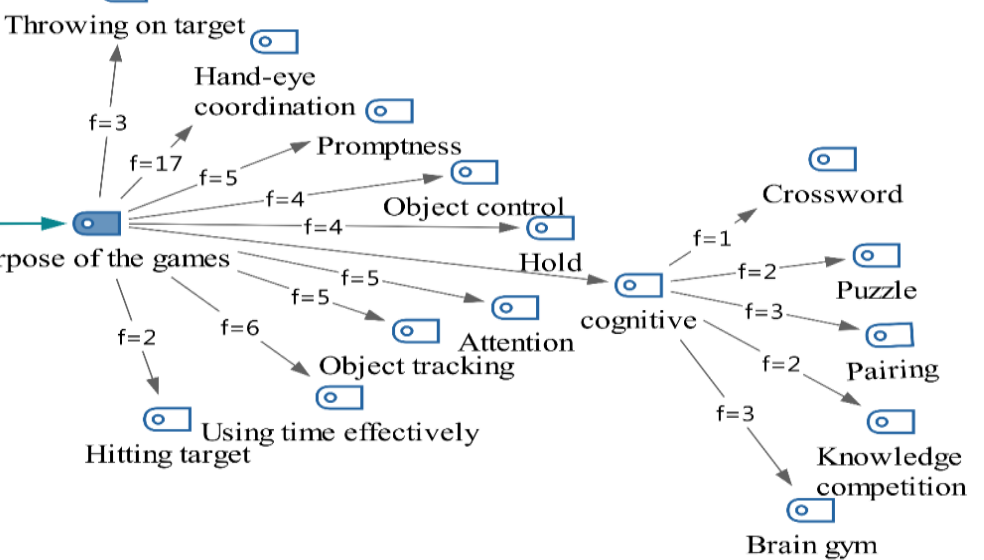

Distance physical

education and sports

lesson content

Figure 5. Educational games theme. 
According to the findings of the study, in the coding made in line with the video content, it is seen that teachers also benefit from educational games in their course contents. It is seen that the uploaded videos are selected from the materials that students who are in the distance education process can easily access. The games are aimed at students' psychomotor skills such as hand-eye coordination, quickness, object control, as well as cognitive skills prepared in a game format such as riddles, puzzles, etc.

\section{Discussions.}

The fact that people spend more time in front of the screen during the pandemic process has had a negative effect on their physical health and quality of life (Hammami, Harrabi, Mohr, \& Krustrup, 2020). Guan et al. (2020) stated that they believe that the pandemic process creates an opportunity for whole society to understand the importance of moving for the children. Home-based activities provided people with an opportunity to be fit and healthy by making simple movements while staying at home (Hammami, Harrabi, Mohr, \& Krustrup, 2020). Physical activity that can be done at home under the supervision of a specialist is distance physical education lessons during the pandemic process. The target of our study was to obtain some clues about how teachers followed a path during the pandemic process by examining the contents of remote physical education classes held in Turkey. As a result of the analyzes made in this direction, three themes emerged under the main theme of "distance physical education and sports lesson content". These are the subthemes of "educational games", "practice" and "theoretical expression". 25 of the uploaded videos were presented as animations and 103 of them were presented as real persons.

In our study, it can be thought that distance pyhsical education classes give an opportunity for promotion of some less popular branches, the reason of which is the lack of the physical environment of schools and facilities, such as swimming, nature sports, developing sports, etc. as well as the popular branches in schools in Turkey such as basketball, volleyball and table tennis (Karakaya and Salici, 2016; Adıgüzel, 2010; Orhan and Yoncalık 2016; Ozcan, Mirzeoğl and Çoknaz, 2016). However, in the analyzes conducted, it is seen that physical education teachers do not prefer such branches and generally prefer the sports branches that students have prior knowledge. Physical education and sports activities at school are held outside the classroom environment such as the school garden and sports hall. Studies have shown that the environment in which the lesson is held and the content of the lesson are found entertaining by students (Temel and Güllü, 2016; Namlı, Temel, \& Güllü, 2017) and that students are happy in the course (Uğraş \& Güllü, 2020). Distance lessons are likely to be less enjoyable than face-to-face lessons. Thus, Varea and González-Calvo (2020) stated in their study that students were happy in face-to-face lessons, but distance physical education lessons made the student unhappy. Children meet their daily physical exercise needs through school travel, physical education and break time, organized sports, games and dance and active play. In contrast, they spend most of their sedentary time at home (Guan et al., 2020). In this process, it can be said that distance physical education lessons have an important role in meeting the movement needs of children. The fact that a significant part of the video content in our study focuses on the movement of students can be considered as a positive finding. However, this should be carried out systematically and within a certain program. In this 
sense, The Republic of Turkey Ministry of National Education has not specified a curriculum on how to implement distance physical education lessons. This situation causes physical education teachers to process their lessons with different application and course contents.

The fact that schools were closed during the Covid 19 process and the fact of students' participation in classes only through technological tools have severely limited the full implementation of physical education and sports lessonsThis situation has provided the opportunity to discuss topics such as health issues, the theoretical explanation of health issues, health and sports relationship issues and branches (game rules, field measurements, history, etc.). Hence, the video content includes general titles such as first aid, benefits of sports, benefits of exercise, as well as specific topics such as the thymus gland and the importance of sleep.In our study, it has been observed that approximately thirty percent of the videos uploaded to youtube are theoretical issues. Although students take physical education lessons at home during the pandemic process, this does not mean that they will stay away from the movement. In our study, it was already revealed that more than half of the videos uploaded to YouTube consist of motion-based content. Students started to be less active as they followed all of their school lessons in front of the screen (Akulwar-Tajane, Parmar, Naik \& Shah, 2020; Wong et al, 2020; Moore et al, 2020). The World Health Organization recommends that school-age children and adults do at least 60 minutes of moderate-intensity physical activity a day (WHO, 2010). Access to physical activity decreased during the pandemic period, as outdoor and group activities were limited. This situation causes mental health negativity, boredom, fear, stress, anxiety and depression on individuals (Burtscher, Burtscher, \& Millet, 2020; Jiménez-Pavón, Carbonell-Baeza, \& Lavie, 2020). In addition, insufficient physical activity causes muscle loss, weight gain and cardiovascular problems (Physical Activity Guidelines Advisory Committee, 2018). Therefore, physical education classes are of critical importance in ensuring that students move in a planned way. Because physical activity has a positive effect on an individual to lead a healthy life, feel physically and psychologically well, and reduce the risk of obesity (McKenzie, Marshall, Sallis, \& Conway, 2000; Fairclough, Hilland, Stratton, \& Ridgers, 2012; Pedersen \& Saltin, 2015; Powell, Paluch, \& Blair, 2011; Castañeda-Vázquez et al., 2020). Ricci et al. (2020) made some suggestions to school-age students during this process of staying at home. They recommend that they move after 30 minutes in front of the screen, and do bone and muscle strengthening exercises such as balance, endurance, flexibility and strength exercises for at least twenty-three minutes daily. It is seen that these movements are frequently made in the content uploaded to Youtube. Since physical activity outside is limited, Hammami, Harrabi, Mohr, and Krustrup (2020) stated in their study that people who do not have the opportunity to do sports outside should do multiple exercise modes (aerobic exercises, body strengthening training, dance exercises and active games). As a result of the examinations made, it was seen that such activities were included in the videos. As a result of the analysis, most of the videos uploaded to youtube are based on movement activities. This result shows that the teachers try not to be detached from the nature of the lesson, and it is important because they are aware of the process and prefer to upload videos that meet the movement needs of the students. However, in their study, Varea and González-Calvo (2020) drew attention to the fact that physical education and sports lessons, which continue remotely, distract the lesson from its 
identity and contain uncertainties about how the lesson will be taught and how it will continue. They argued that the lack of direct contact with the students made the lesson passive. However, they stated that it provides opportunities for them to use technology better and this situation will provide opportunities for individual learning in the future. The sudden entry of the Covid 19 pandemic into our lives and the necessity for students to attend classes at home make everbody think that the solutions that are tried to be done quickly for physical education and sports lessons may have positive and negative reflections. It was observed that the distance education video content uploaded to Youtuba was determined by the teachers. Because physical education and sport in distance education process does not have a general curriculum for the course in Turkey. At the same time, no recommendations have been taken for physical education and sports lessons in distance education. The process is left to the discretion of the teachers.

As a result of the analysis, it was observed that physical education teachers included educational games in the content they uploaded to youtube. While preparing the content of educational games, teachers aimed to ensure the participation of all students by including materials that students can easily reach at home. Because educational game includes activities that give children fun and joy as well as children being healthy, gaining good habits in their personal behaviors (Akandere, 2006). At the same time, educational games contribute to the increase of throwing force, speed, claw force, agility and flexibility (Aynacıyan \& Özer, 2020). Schools are closed, social isolation brings more time at home and children and young people get bored at home, and their anxiety levels increase (Jiaove et al, 2020; Liu, Bao, Huang, Shi \& Lu, 2020; Zhai \& Du, 2020; Lee, 2020; Carroll et al, 2020; Banerjee and Rai, 2020; Williams, Armitage, Tampe, \& Dienes, 2020), and this makes children not have enough fun. Educational games are more important in the covid 19 process in order to develop cognitive and psychomotor skills while having fun and having fun. It is important for children to participate in and enjoy physical activity in their spare time as part of their wider life skills. (Shahidi, Stewart Williams, \& Hassani, 2020). As a result of the analysis of the videos, it is seen that the teachers care about this situation and they try to create efficient and entertaining content for the children in the videos they upload.

\section{Conclusion and Suggestions.}

It was concluded that it was aimed to meet the movement needs of the students through the videos uploaded under the title of physical education and sports lessons in distance education on YouTube, that the students were supported with information within the framework of "health - sports" about what they should do to protect their health, and that the process was tried to be made fun through educational games during their stay at home. At the end of the study, it was determined that the videos uploaded to YouTube were personal videos rather than corporate videos, and it was concluded that the content of these videos was created according to the personal opinions of the uploader. Considering the reasons for uploading the videos, it has been observed that they aim to contribute to the students who stay at home, albeit small.

According to the current conditions, it is essential to provide an in-service training course for teachers on how to handle physical education and sports lessons through distance education. In addition, preparing a curriculum or a draft program related to physical education and sports lessons can increase the efficiency of the lesson 


\section{References.}

- Adıgüzel, R. (2010). İlköğretim okulları II. kademe öğrencilerinin spora bakış açılarının ve spor alışkanlıklarının değerlendirilmesi. Yüksek Lisans Tezi, Erciyes Üniversitesi, Sağlık Bilimleri Enstitüsü, Kayseri

- Akalın, T. C., \& Gümüş, M. Investigation of secondary school students' participation in physical education lessons with distance education in the pandemic process. African Educational Research Journal, 8(2) 266-272.

- Akandere, M. (2006). Eğitici okul oyunları. 3. Baskı. Ankara: Nobel Yayın Dağıtım.

- Akulwar-Tajane, I., Parmar, K. K., Naik, P. H., \& Shah, A. V. (2020). Rethinking Screen Time during COVID-19: Impact on Psychological Well-Being in Physiotherapy Students. International Journal of Clinical and Experimental Medicine Research, 4(4), 201-216. https://doi.org/10.26855/ijcemr.2020.10.014

- Allen, I. E., \& Seaman, J. (2016). Online report card: Tacking online education in the United States. Newburyport, MA: Babson Survey Research Group

- Altıparmak, M., Kurt, İ. D., \& Kapıdere, M. (2011). "E-Öğrenme ve uzaktan eğitimde açık kaynak kodlu öğrenme yönetim sistemleri” Akademik Bilişim'11 - XIII. Akademik Bilişim Konferansı Bildirileri Kitabı, (pp.319-327). Malatya.

- Aynacıyan, N., \& Özer, M. K. (2020). Çocuklara Uygulanan Eğitsel Oyun Aktivitelerinin Motorik Özelliklerine Etkisi. Journal Of Health And Sport Sciences, 3(1), 24-31.

- Banerjee, D. and Rai, M. (2020), "Social isolation in Covid-19: the impact of loneliness", The International Journal of Social Psychiatry, 66,(6), 525-527. https://doi.org/10.1177\%2F0020764020922269

- Brooks, S. K., Webster, R. K., Smith, L. E., Woodland, L., Wessely, S., Greenberg, N., \& Rubin, G. J. (2020). The psychological impact of quarantine and how to reduce it: rapid review of the evidence. The Lancet. 395, 912-920. https://doi.org/10.1016/S0140-6736(20)30460-8

- Burtscher, J., Burtscher, M., \& Millet, G. P. (2020). (Indoor) isolation, stress and physical inactivity: vicious circles accelerated by Covid-19?. Scandinavian journal of medicine \& science in sports. 30(8), 1544-45. https://doi.org/10.1111/sms.13706

- Cachón-Zagalaz, J., Sánchez-Zafra, M., Sanabrias-Moreno, D., González-Valero, G., Lara-Sánchez, A. J., and Zagalaz-Sánchez, M. L. (2020). Systematic review of the literature about the effects of the COVID-19 pandemic on the lives of school children. Front. Psychol. 11:569348. https://doi.org/10.3389/fpsyg.2020.569348

- Carroll, N., Sadowski, A., Laila, A., Hruska, V., Nixon, M., Ma, D. W., \& Haines, J. (2020). The impact of COVID-19 on health behavior, stress, financial and food security among middle to high income Canadian families with young children. Nutrients, 12(8), 2352. https://doi.org/10.3390/nu12082352

- Castañeda-Vázquez, C., Corral-Pernía, J. A., and Chacón-Borrego, F. (2020). Influencia de la actividad física sobre la capacidad aeróbica en escolares españoles. J. Sport Health Res. 12(Suppl. 1), 31-38.

- Cheng, X., Dale, C., \& Liu, J. (2008). Statistics and social network of youtube videos. In 2008 16th Interntional Workshop on Quality of Service (pp. 229-238). IEEE.

- Elo, S., \& Kyngäs, H. (2008). The qualitative content analysis process. Journal of advanced nursing, 62(1), 107-115. https://doi.org/10.1111/i.1365-2648.2007.04569.x 
- Fairclough, S., Hilland, T., Stratton, G. ve Ridgers, N. (2012). Am I Able? Is It Worth It? Adolescent Girls' Motivational Predispositions to School Physical Education: Associations With Health-Enhancing Physical Activity. European Physical Education Review, 18(2), 147-158. https://doi.org/10.1177/1356336x12440025.

- Founaud, M. P., and González-Audicana, C. (2020). La vivencia emocional en los estudiantes de Educación Primaria en Educación Física. J. Sport Health Res. 12(Suppl. 1), 15-24.

- Goad, T., Towner, B., Jones, E., \& Bulger, S. (2019). Instructional Tools for Online Physical Education: Using Mobile Technologies to Enhance Learning. Journal of Physical Education, Recreation \& Dance, 90(6), 40-47. https://doi.org/10.1080/07303084.2019.1614118

- Guan, H., Okely, A. D., Aguilar-Farias, N., Cruz, B., Draper, C. E., El Hamdoouchi, A., et al. (2020). Promoting healthy behaviours among children during the COVID19 pandemic. Lancet Child Adolesc. Health 4, 416-418. https://doi.org/10.1016/S2352-4642(20)30131-0

- Hammami, A., Harrabi, B., Mohr, M., \& Krustrup, P. (2020). Physical activity and coronavirus disease 2019 (COVID-19): specific recommendations for home-based physical training. Managing Sport and Leisure, 1-6. https://doi.org/10.1080/23750472.2020.1757494

- Ivanov, V., \& Tzankova, J. (2020). Onlıne distance education on wordpress web based platform as an innovation in the learnıng process of sports students from medical unıversıty - sofıa durıng the pandemıc of covid-19. Pedagogy. 92(7). 14351.

- Jackson, C., Vynnycky, E., ve Mangtani, P. (2016). The relationship between school holidays and transmission of influenza in England and wales. American journal of epidemiology, 184(9), 644-651. https://doi.org/10.1093/aje/kww083

- Jiménez-Pavón, D., Carbonell-Baeza, A., \& Lavie, C. J. (2020). Physical exercise as therapy to fight against the mental and physical consequences of COVID-19 quarantine: Special focus in older people. Progress in cardiovascular diseases. 63(3): 386-388. https://dx.doi.org/10.1016\%2Fi.pcad.2020.03.009

- Karakaya, E ve Salici, O . (2016). Determination of the metaphorical perception of the students, aged 11 to 13 , studying about popular sports branches in Isparta. International Journal of Social Sciences and Education Research , 2(3) , 855-869 . https://doi.org/10.24289/ijsser.279029

- Kırık, M.A. (2014). Uzaktan Eğitimin Tarihsel Gelişimi ve Türkiye'deki Durumu, Marmara Illetişim Dergisi, 21, 73-94.

- La Velle, L., Newman, S., Montgomery, C., \& Hyatt, D. (2020). Initial teacher education in England and the Covid-19 pandemic: challenges and opportunities. Journal of Education for Teaching, 1-13. https://doi.org/10.1080/02607476.2020.1803051

- Lee J. Mental health effects of school closures during COVID-19. Lancet. Child Adolesc. Health, 23(52)-4642(20)30109-7. https://doi.org/10.1016/S23524642(20)30109-7.

- Lei, S. A., \& Gupta, R. K. (2010). College distance education courses: Evaluating benefits and costs from institutional, faculty and students' perspectives. Education, 130(4), 616-631. 
- Liu J.J., Bao Y., Huang X., Shi J. ve Lu L. Mental health considerations for children quarantined because of COVID-19. Lancet. Child Adolesc. Health, 4(5):347-349. https://doi.org/10.1016/S2352-4642(20)30096-1.

- Macnamara, J. R. (2005). Media content analysis: Its uses, benefits and best practice methodology. Asia Pacific Public Relations Journal, 6(1), 1.

- Mattioli, A. V., Sciomer, S., Cocchi, C., Maffei, S., \& Gallina, S. (2020). Quarantine during COVID-19 outbreak: changes in diet and physical activity increase the risk of cardiovascular disease. Nutrition, Metabolism and Cardiovascular Diseases, 30(9), 1409-1417. https://doi.org/10.1016/j.numecd.2020.05.020

- Mayring, P. (2014). Qualitative content analysis: theoretical foundation, basic procedures and software solution.. Klagenfurt. Retrieved January 11.2020. https://nbn-resolving.org/urn:nbn:de:0168-ssoar-395173

- McKenzie, T. L., Marshall, S. J., Sallis, J. F. ve Conway, T. L. (2000). Leisure-time Physical Activity in School Environments: An Observational Study Using SOPLAY. Preventive Medicine, 30(1), 70-77. https://doi.org/10.1006/pmed.1999.0591

- Moore, S. A., Faulkner, G., Rhodes, R. E., Brussoni, M., Chulak-Bozzer, T., Ferguson, L. J., ... \& Tremblay, M. S. (2020). Impact of the COVID-19 virus outbreak on movement and play behaviours of Canadian children and youth: a national survey. International Journal of Behavioral Nutrition and Physical Activity, 17(1), 1-11. https://doi.org/10.1186/s12966-020-00987-8

- Muntaner-Mas, A., Vidal-Conti, J., Cantallops, J., Borràs, P. A., \& Palou, P. (2017). Obesity and physical activity patterns among Balearic Islands children and adolescents: a cross-sectional study. Journal of Human Sport and Exercise, 12(2), 333-348.

- Nafisah, S. B., Alamery, A. H., Al Nafesa, A., Aleid, B., \& Brazanji, N. A. (2018). School closure during novel influenza: a systematic review. Journal of Infection and Public Health, 11(5), 657-661. https://doi.org/10.1016/j.jiph.2018.01.003

- Namlı, A., Temel, C. ve Güllü, M. (2017). Ortaokul öğrencilerinin beden eğitimi dersine ilişkin ürettikleri meaforlar. Kastamonu Education Journal, 25(2), 479-496.

- Odabaş, H. (2003). Internet Tabanlı Uzaktan Eğitim ve Bilgi ve Belge Yönetimi. Türk Kütüphaneciliği, 17(1), 22-36.

- Orhan, R., \& Yoncalık, O. (2016). Türkiye'deki ortaokul öğrencilerinin beden eğitimi ve spor alışkanlıkları. Kırıkkale Üniversitesi Sosyal Bilimler Dergisi, 6(1), 353-376.

- Özbay, Ö. (2015). Dünyada ve türkiye'de uzaktan eğitimin güncel durumu. Uluslararası Eğitim Bilimleri Dergisi, 5. 376-394.

- Özcan, G., Mirzeoğlu A.D., \& Çoknaz, D. (2016). Öğrenci gözüyle beden eğitimi ve spor dersi ve öğretmeni. Abant lzzet Baysal Üniversitesi Eğitim Fakültesi Dergisi, 16 (1), 270-291.

- Özer, M. (2020). Türkiye'de covıd-19 salgını sürecinde MiLLI EĞiTiM BAkanlığı tarafından atılan politika adımları Educational Policy Actions by the Ministry of National Education in the times of COVID-19. Kastamonu Education Journal, 28(3), 1124-1129.

- Patton, M. Q. (2002). Qualitative research and evaluation methods (3rd ed.). Thousand Oaks, CA: Sage.

- Pedersen, B. K., \& Saltin, B. (2015). Exercise as medicine - evidence for prescribing exercise as therapy in 26 different chronic diseases. Scandinavian 
Journal of Medicine \& Science in Sports, 25(S3), 1-72. https://doi.org/10.1111/sms. 12581.

- Physical Activity Guidelines Advisory Committee. (2018). Physical activity guidelines advisory committee scientific report. Washington, DC: US Department of Health and Human Services. Retrieved January 02.2021. https://www.hhs.gov/ash/advisory-committees/2018-physical-activityguidelinesadvisory-committee.html.

- Pietrobelli, A.; Pecoraro, L.; Ferruzzi, A.; Heo, M.; Faith, M.; Zoller, T.; Antoniazzi, F.; Piacentini, G.; Fearnbach, S.N.; Heymsfield, S.B. Effects of COVID-19 Lockdown on Lifestyle Behaviors in Children with Obesity Living in Verona, Italy: A Longitudinal Study.(2020). Obesity, 28, 1382-1385. https://doi.org/10.1002/oby.22861

- Powell, K. E., Paluch, A. E., \& Blair, S. N. (2011). Physical activity for health: What kind? How much? How intense? On top of what? Annual Review of Public Health, 32(1), 349-365. https://doi.org/10.1146/ annurev-publhealth-031210-101151.

- Rundle, A, G., Park, Y., Herbstman, J, B., Kinsey, E, W., \& Wang, Y, C. (2020). COVID19-related school closings and risk of weight gain among children. Obesity (Silver Spring). 28:1008-1009. https://doi.org/10.1002/oby.22813

- Sardinha, L. B., Marques, A., Minderico, C., \& Ekelund, U. (2017). Cross-sectional and prospective impact of reallocating sedentary time to physical activity on children's body composition. Pediatric obesity, 12(5), 373-379. https://doi.org/10.1111/ijpo.12153

- Shahidi, S. H., Stewart Williams, J., \& Hassani, F. (2020). Physical activity during COVID-19 quarantine. Acta Paediatrica, 109(10), 2147-2148. https://doi.org/10.1111/apa.15420

- Silva, R. C. A., Silva, V. L. D. F., \& Silva, A. P. (2019). Distance learning for teaching in physical education. Motriz: Revista de Educação Física, 25(1). https://doi.org/10.1590/s1980-6574201900010002

- Temel, C. ve Güllü, M. (2016). Draw a Physical Education Lesson. Education and Science, 41(183), 351-361.

- Tzifopoulos, M. (2020). In the shadow of Coronavirus: Distance education and digital literacy skills in Greece. International Journal of Social Science and Technology, 5(2), 1-14.

- Uğraş, S., \& Güllü, M. (2020). Ortaokulda öğrenim gören öğrencilerin beden eğitimi dersindeki mutluluk düzeyleri ile yaşam doyumları arasındaki ilişkinin incelenmesi: Yapısal eşitlik modeli. Journal of History School 13(45). 583-599. http://dx.doi.org/10.29228/Joh40276

- Valois, R. F., Zullig, K. J., Huebner, E. S., \& Drane, J. W. (2004). Physical activity behaviors and perceived life satisfaction among public high school adolescents. Journal of school health, 74(2), 59-65. https://doi.org/10.1111/i.17461561.2004.tb04201.x

- Varea, V., \& González-Calvo, G. (2020). Touchless classes and absent bodies: teaching physical education in times of Covid-19. Sport, Education and Society, 115. https://doi.org/10.1080/13573322.2020.1791814 
- Von Hippel, P. T., \& Workman, J. (2016). From kindergarten through second grade, US children's obesity prevalence grows only during summer vacations. Obesity, 24(11), 2296-2300. https://doi.org/10.1002/oby.21613

- Who (2020) Coronavirus disease (COVID-19) pandemic. Retrieved January 06, $2020 \mathrm{https}: / / \mathrm{www}$.who.int/emergencies/diseases/novel-coronavirus.

- WHO. (2010). World Health Organization Global recommendations on physical activity for health. Geneva, Switzerland.

- Williams, S.N., Armitage, C.J., Tampe, T. and Dienes, K. (2020), "Public perceptions and experiences of social distancing and social isolation during the COVID-19 pandemic: a UK-based focus group study", medRxiv, https://doi.org/10.1101/2020.04.10.20061267

- Wong, C. W., Andrew, T. S. A. I., Jonas, J. B., Ohno-Matsui, K., James, C. H. E. N., Marcus, A. N. G., \& Ting, D. S. W. (2020). Digital Screen Time During COVID19 Pandemic: Risk for a Further Myopia Boom?. American journal of ophthalmology. 333-337. https://doi.org/10.1016/i.ajo.2020.07.034

- Woods, J., Hutchinson, N., Powers, S., Roberts, W., Gomez-Cabrera, M., Radak, Z., Berkes, I., Boros, A., Boldogh, I., Leeuwenburgh, C., Coelho-Júnior, J., Marzetti, E., Cheng, Y., Liu, J., Durstine, L., Sun, J., \&, Li Li Ji, S. (2020). The COVID-19 Pandemic and Physical Activity. Sports Medicine and Health science, 2(2)55-64. https://doi.org/10.1016/i.smhs.2020.05.006.

- Workman, J. (2020). How Much may covid-19 school closures Increase childhood obesity?. Obesity, 28(10), 1787-1787. https://doi.org/10.1002/oby.22960

- Xu, D., \& Xu, Y. (2019). The promises and limits of online higher education: Understanding how distance education affects access, cost, and quality. Washington, DC: American Enterprise Institute.

- Yalçınkaya, S. (2006). "Web Tabanlı Uzaktan Eğitim Sistemi ve Çukurova Üniversitesi Öğretim Elemanlarının Yatkınıkları", Yüksek Lisans Tezi, Çukurova Üniversitesi Sosyal Bilimler Enstitüsü İ̧̧letme Anabilim Dalı, Adana.

- Yıldırım A, Şimşek H. (2011) Sosyal bilimlerde nitel araştırma yöntemleri, 8. Baskı Ankara, Seçkin Yayıncllık.

- Zhai, Y. ve Du, X. (2020). Mental health care for international Chinese students affected by the COVID-19 outbreak. The Lancet Psychiatry, 7(4), e22. https://doi.org/10.1016/s2215-0366(20)30089-4

- Zhong, B. L., Luo, W., Li, H. M., Zhang, Q. Q., Liu, X. G., Li, W. T., ve Li, Y. (2020). Knowledge, attitudes, and practices towards COVID-19 among Chinese residents during the rapid rise period of the COVID-19 outbreak: a quick online crosssectional survey. International journal of biological sciences, 16(10), 1745. https://dx.doi.org/10.7150\%2Fijbs.45221

- Zullig, K. J., \& White, R. J. (2011). Physical activity, life satisfaction, and self-rated health of middle school students. Applied Research in Quality of Life, 6(3), 277289. 